\title{
Intrahepatic Bile Duct Cancer cM1 TNM Finding v8
}

National Cancer Institute

\section{Source}

National Cancer Institute. Intrahepatic Bile Duct Cancer cM1 TNM Finding v8. NCI

Thesaurus. Code C134581.

Intrahepatic bile duct cancer with distant metastasis. (from AJCC 8th Ed.) 